\title{
RESULTS OF TWO MORPHOLOGICAL PRACTICAL METHODS FOR SEX DETERMINATION IN JAPANESE QUAIL
}

\author{
Ensaf A. EI Full and Mona S. Ragab \\ Poult. Prod. Dept. Fac. of Agric., Cairo Univ., Fayoum Branch. \\ ABSTRACT: \\ Shank length measurements of $\geq 35 \mathrm{~mm}$ for females and $<35$ \\ $\mathrm{mm}$ for males was used to predict sexes in Japanese quail at 10, \\ $17,24,31,38$ and 45 days of age in 827 Japanese quail chicks. \\ Shank length between sexes was found to differ $(\mathrm{P}<0.01)$ as early \\ as 17 days of age and was maintained thereafter. The best \\ prediction of sexes was made at 24 days of age; the accuracy for \\ predicting females was higher than for males (96.1 vs. 95.9\%). \\ This technique requires only a single shank measurement taken at \\ 24 days of age and provides the breeder with a reliable way of \\ separating sexes for purposes of marketing and selection of \\ breeders at relatively earlier ages especially in white strains. There \\ was a second method of sex determination through plumage \\ dimorphism (feather sexing) with 95\% accuracy at 24 days of age. \\ Therefore, either shank length or feather dimorphism would offer \\ valid methods for separating sexes of Japanese quail. \\ Key words: Morphological, practical methods, sex determination, Japanese \\ quail
}

\section{INTRODUCTION}

Sexes of some gallinaceous species are difficult to distinguish because of a lack of plumage dimorphism (Woodard et al., 1986). One example is the Japanese quail, males and females have identical plumage during earlier weeks of age. Much of the quail's adult plumage is present by 10 weeks of age, but adult stature is not attained until 15 to 16 weeks of age. The problem is more pronouncing in white strain of Japanese quail. Walker( 1996) reported that determining the sex of birds can be done by observing feather patterns and coloration at 12 weeks of age or by looking at the mandible (lower beak) color slightly sooner. Mandibles of males become uniformly black by 8 to 10 weeks old, while those of females are dull yellow or pale.

A method for determining sex of one day-old chicks can be accomplished by one of two methods: 1) vent sexing or 2) feather sexing. Each method has difficulties that make it unsuitable for use by the small flock owner. Vent sexing relies on the visual identification of sex based on appearance of sexual organs whereas feather sexing is based on differences in feather characteristics at hatch time. Vent sexing of chicks at hatching has complications that make it more difficult than sex determination of most other animals because the sexual organs of birds are located within the body and are not easily distinguishable. The copulatory organ of chickens can be identified as male or female by shape, but there are over fifteen different shapes to consider. Therefore, few people have experience with determining the sex of birds because of the difficult nature of the process. Most of these highly trained individuals are employed by large commercial hatcheries. The training to be a

Fayoum J. Agric. Res. \& Dev., Vol.19, No.1, January, 2005 
chick sexier is so difficult and lengthy that the average poultry owner finds it unjustifiable.

Feather sexing is based on feather characteristics that differ between male and female chicks. The method is very easy to learn by the poultry man, but the feather appearances are determined by specially selected genetic traits that must be present in the chick strain. Most strains (breeds) of chickens do not have these feather sexing characteristics and feathering of both sexes appear identical. The most convenient method of sexing chickens by the small flock owner is to care for the birds until they begin showing the natural secondary characteristics of their sex. In some varieties the feathers of each sex will develop a characteristic color pattern that identifies it. These varieties of birds are similar to the feather-sex strains of chickens discussed above. Sexing based on secondary sex characteristics can usually be performed after chicks attain 4 to 6 weeks of age (URL, 2003).

A method for determining the sex one day-old chukars was described by Siopes and Wilson (1973). They used a modified vent-sexing technique described for domestic poultry with $95 \%$ accuracy. Because accurate vent sexing requires much practice, it is not widely used by quail growers or biologists. Another technique to determine sex of chukars was described by Weaver and Haskell (1968) who found that flight primaries one and three were generally longer in males than females at 17 weeks of age. In a redlegged partridge, Pepin (1985) found significant differences between sexes for eight different morphological variables, but considered only body weight and wing length as main determinants of sexes.

Studies of domestic fowl have revealed that certain morphological dimensions are correlated with sex. Several investigators found that body weights of female Japanese quail (Coturnix coturnix japonica) were significantly larger than males at three weeks of age (Kawahara, 1971, El Full, 2000 and 2001).

Live shank length was more highly correlated with body weight than other indirect growth parameters as reported by Lerner (1937), Jaap (1938) and El Full and Ragab (2004). Lerner (1937) found that maximum shank growth was reached much earlier than maximum lean tissue weight. Because both body weight and shank length are highly heritable (Lerner, 1939, Kondra and Shoffner, 1955 and El Full et al., 2001). Thus, considering it likely that differences in rates of development would offer a valid method of separating sexes in addition to studying the plumage dimorphism at specific age of Japanese quail. And to determine if shank length and feather characteristics were valid determinants of sex in Japanese quail.

\section{MATERIALS AND METHODS}

This work was carried out in the Poultry Research Station, Poultry Production Department, Faculty of Agriculture at Fayoum, Cairo University during the period from December 2002 to February 2003. All chicks were wing-banded and brooded in floor brooders. The appropriate feeding, vaccination and management practices were kept uniform as possible throughout the experimental period. Chicks were fed a commercial starter ration (24\% CP and 2900 k.cal. ME/kg) from hatch throughout the

Fayoum J. Agric. Res. \& Dev., Vol.19, No.1, January, 2005 
RESULTS OF TWO MORPHOLOGICAL PRACTICAL MET.

experimental period. Feed and water were offered $a d l i b$. The minerals and vitamins were adequately supplied to cover the requirements according to the NRC (1994).

Live body weight (LBW) and shank length (SL) were measured at 10 , $17,24,31,38$ and 45 days of age in 827 Japanese quail chicks. Shank length was measured as the distance from the foot pad to the top of the hock joint in legs flexed at $90^{\circ}$ from the tibia, using a caliper to the nearest $0.01 \mathrm{~mm}$. All shank measurements in this study were made by the same person. Chicks were brooded in multi-deck batteries at an appropriate temperatures starting with 100 ${ }^{\circ} \mathrm{F}$ during the first week and decreased by $5^{\circ} \mathrm{F}$ each week thereafter till $80^{\circ} \mathrm{F}$ during the fifth week and a daily 23-hr light photoperiod. Differences in means were tested according to Duncan (1955). Data of body weight and shank length were subjected to regression analysis, considering shank length dependent on body weight and assumed that any alteration of body weight would reflect a change in shank length. The following regression models were used to select the most suitable curve which has the highest coefficient of determination $\left(\mathrm{R}^{2}\right)$ :

Linear model: $\hat{\mathbf{Y}}=\mathbf{a}+\mathbf{b X}$.

where ' $\hat{\mathbf{Y}}$ ': is the predicted LBW, ' $\mathrm{X}$ ' : is the SL, ' $a$ ' and ' $b$ ' are the constants to be determined through method of least squares.

Quadratic model: $\hat{\mathbf{Y}}=\mathbf{a}+\mathbf{b X}+\mathbf{b X} \mathbf{X}^{2}$.

Cubic model: $\hat{\mathbf{Y}}=\mathbf{a}+\mathbf{b X}+\mathbf{b X} \mathbf{X}^{2}+\mathbf{b} \mathbf{X}^{3}$.

Power model: $\hat{\mathbf{Y}}=\mathbf{a} \mathbf{X}^{\mathbf{b}}$.

Exponential model: $\hat{\mathbf{Y}}=\mathbf{a} \mathrm{e}^{\mathrm{bx}}$.

where ' $\mathrm{Y}$ ': is the predicted LBW, ' $\mathrm{X}$ ': is the $\mathrm{SL}$, ' $\mathrm{b}$ ' is the constant to be determined through method of least squares.

Differences between observed and expected count of males and females diagnosed at different ages were subjected to Chi-square test. The true sex of the chicks was determined at sexual maturity ( 45 days of age). So, paired differences between determined sexes at specific age vs. actual sex diagnosed at 45 days of age were tested by Student's t-test (SPSS, 1997).

\section{RESULTS AND DISCUSSION}

Sex determination through shank length measured at different ages

Body weight in male and female of Japanese quail was about $87.53 \%$ and $79.47 \%$ at 31 days of age and $97.10 \%$ and $95.92 \%$ at 38 days of age as compared to body weight measured at 45 days of age, respectively as shown in Table 1. A significant difference $(\mathrm{P}<0.001)$ in body weight by sex first occurred at 17 days of age and was maintained thereafter. There were only minimal gains in body weight from 38 to 45 days of age, $4.85 \mathrm{~g}$ for males and $7.61 \mathrm{~g}$ for females. Sex-related differences in body weight increased with age ranged from $1.04 \mathrm{~g}$ to 33.57 at 45 days of age (Fig. 1). Shank growth in both sexes was $89 \%$ and $89 \%$ at 38 days of age compared to shank length measured at 45 days of age at which average shank in females was $0.58 \mathrm{~mm}$ longer than males $(39.75$ vs. 39.17, Table 1). Shank length between sexes was found to differ $(\mathrm{P}<0.01)$ as early as 17 days of age and was maintained thereafter, except 24days of age as shown in Fig. 1.

In order to determine which trait was superior for separating sexes, regression curves were calculated for body weight and shank length at different

Fayoum J. Agric. Res. \& Dev., Vol.19, No.1, January, 2005 
ages. It was assumed that the most accurate separation would be at or near 24 days of age when shank growth was complete (about 85\% was complete for both sexes). From several regression curves studied it was apparent that shank lengths $\geq 35 \mathrm{~mm}$ for females and $<35 \mathrm{~mm}$ for males gave the best separation. Significant sex differences in body weight occurred as early as 17 days of age, but body weight was variable in this regard, and combining this trait with shank length did not improve the accuracy of sex determinations.

Table 1. Means $\pm \mathrm{SE}$ for age effect as well as the relative values of body weight and shank length as measured at different ages in Japanese quail.

\begin{tabular}{|c|c|c|c|c|c|c|}
\hline \multirow{2}{*}{$\begin{array}{l}\text { Age, } \\
\text { days }\end{array}$} & \multicolumn{3}{|c|}{ Live body weight, g } & \multicolumn{3}{|c|}{ Live shank length, mm } \\
\hline & 万* & o* & Age effect & $0^{1 *}$ & q* & Age effect \\
\hline 10 & $29.14 \%$ & $24.79 \%$ & $49.33 \pm 0.28^{f}$ & $65.61 \%$ & $65.58 \%$ & $29.09 \pm 0.15^{d}$ \\
\hline 17 & $43.06 \%$ & $44.95 \%$ & $81.25 \pm 0.34^{\mathrm{e}}$ & $79.31 \%$ & $79.04 \%$ & $35.10 \pm 0.13^{c}$ \\
\hline 24 & $69.91 \%$ & $60.32 \%$ & $119.19 \pm 0.56^{d}$ & $85.09 \%$ & $84.55 \%$ & $37.59 \pm 0.12^{b}$ \\
\hline 31 & $87.53 \%$ & $79.47 \%$ & $153.20 \pm 0.70^{c}$ & $88.30 \%$ & $88.13 \%$ & $39.11 \pm 0.11^{\mathrm{a}}$ \\
\hline 38 & $97.10 \%$ & $95.92 \%$ & $178.06 \pm 0.95^{b}$ & $89.14 \%$ & $89.01 \%$ & $39.49 \pm 0.09^{a}$ \\
\hline 45 & $100.00 \%$ & $100.00 \%$ & $184.29 \pm 1.06^{\mathrm{a}}$ & $100.00 \%$ & $100.00 \%$ & $44.34 \pm 0.10^{a}$ \\
\hline
\end{tabular}

: female, $\delta^{\uparrow}$ : male, ${ }^{*}$ : Relative to trait measured at 45days of age. Values having different superscripts within the same column of age effect are significantly different $(\mathrm{P} \leq 0.05)$.

Using a shank length of $35 \mathrm{~mm}$, individual chicks were separated for sex at $10,17,24,31,38$ and 45 days of age. The true sex of the chicks was determined at sexual maturity. Similar findings were reported by Woodard et al. (1986). The most accurate results were found at 24 days of age (96\% for both sexes). At 24 days of age, females were more accurately predicted than males $(96.1 \%$ vs. $95.9 \%$ ). The error of classifying females decreased with age, whereas the male error increased with age to 31 days of age as shown in Table 2).

Table 2. Accuracy of predicting sex of Japanese quail using shank measurements of $\geq 35 \mathrm{~mm}$ for females and $<35 \mathrm{~mm}$ for males from 10 to 45 days of age.

\begin{tabular}{|c|c|c|c|c|c|c|c|}
\hline \multirow{3}{*}{$\begin{array}{l}\text { Parameters } \\
\%\end{array}$} & \multicolumn{7}{|c|}{ Age in days } \\
\hline & \multicolumn{3}{|c|}{ Juvenile } & \multicolumn{3}{|c|}{ Adult } & \\
\hline & $\mathbf{N}$ & 10 & 17 & 24 & 31 & 38 & 45 \\
\hline Females $<35 \mathrm{~mm}$ & 413 & 48.7 & 47.2 & 3.9 & 1.1 & 0.7 & 0.0 \\
\hline Accuracy & & $51.3 \%$ & $52.8 \%$ & $96.1 \%$ & $98.9 \%$ & $99.3 \%$ & $100 \%$ \\
\hline Males < $35 \mathrm{~mm}$ & 414 & 49.1 & 51.6 & 4.1 & 0.60 & 0.70 & 0.0 \\
\hline Accuracy & & $50.9 \%$ & $48.4 \%$ & $95.9 \%$ & $99.4 \%$ & $99.3 \%$ & $100 \%$ \\
\hline Females $\geq 35 \mathrm{~mm}$ & 413 & 0.4 & 37.0 & 46.8 & 50.5 & 54.0 & \\
\hline Accuracy & & $99.6 \%$ & $63.0 \%$ & $53.2 \%$ & $49.5 \%$ & $46.0 \%$ & \\
\hline Males $\geq 35 \mathrm{~mm}$ & 414 & 0.4 & 28.9 & 44.2 & 48.6 & 44.1 & \\
\hline Accuracy & & 99.6 & 71.1 & 55.9 & 51.4 & 55.9 & \\
\hline
\end{tabular}

From several regression curves studied it was apparent that the power model $\left(\hat{\mathbf{Y}}=\mathbf{a} \mathbf{X}^{\mathbf{b}}\right)$ was the best curve expressing the relationship between SL on LBW at different ages in both males and females associating with $\mathrm{R}^{2}$ of 0.896 and 0.933 , respectively. It can be seen that $89.6 \%$ of the variation in males SL was resulted by variations in LBW. However, females had higher $\mathrm{R}^{2}$ of $93.3 \%$ than males (Table 5 and Fig.2).

Fayoum J. Agric. Res. \& Dev., Vol.19, No.1, January, 2005 
Fig. 1. Average live body weight and shank length as measured at different ages in Japanese quail
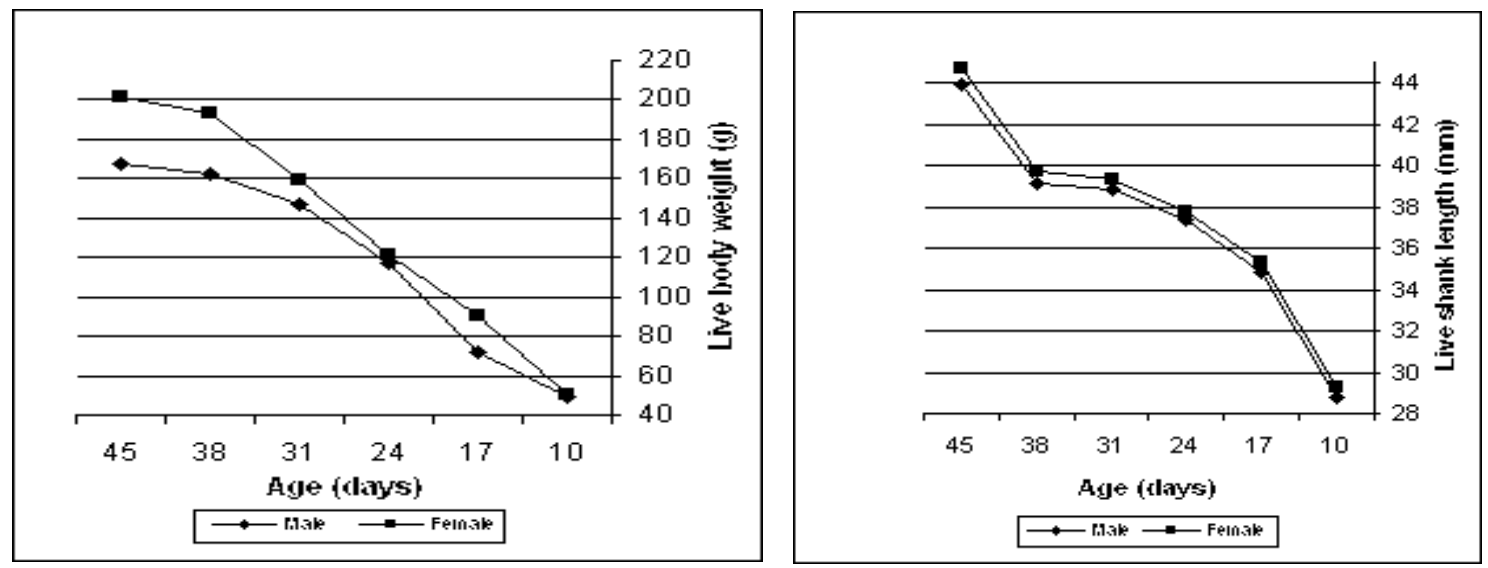

Fig. 2. Regression for shank length on body weight at different ages.

Males

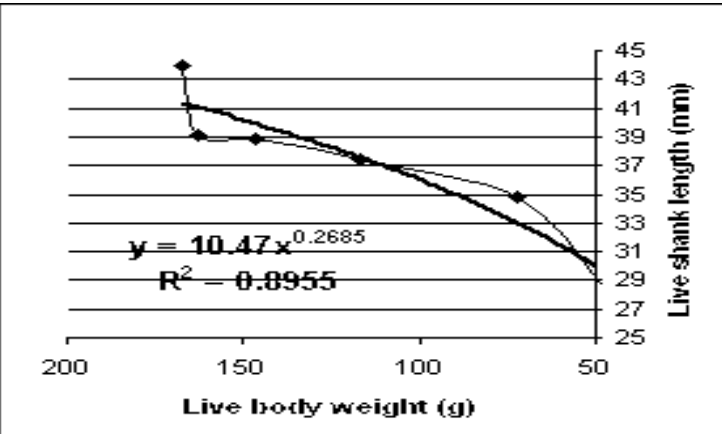

Females

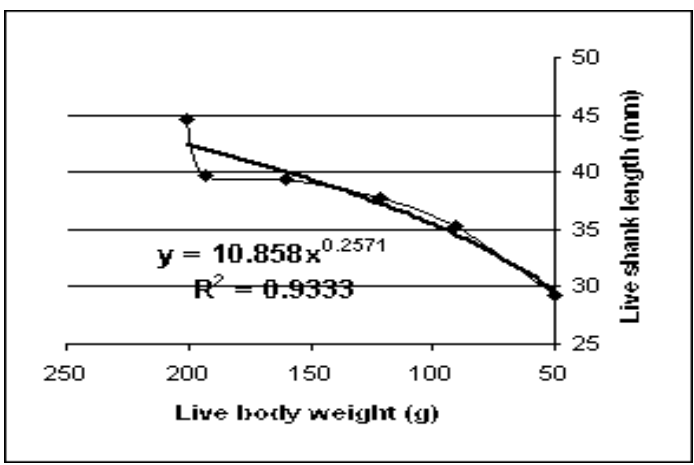

Fig. 3. Regression for body weight and shank length at 24 days of age in Japanese quail.

\section{Males}

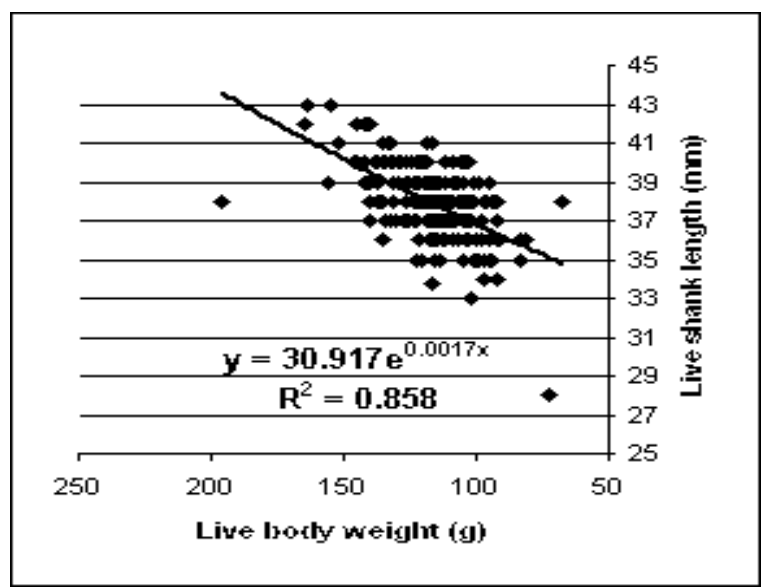

Females

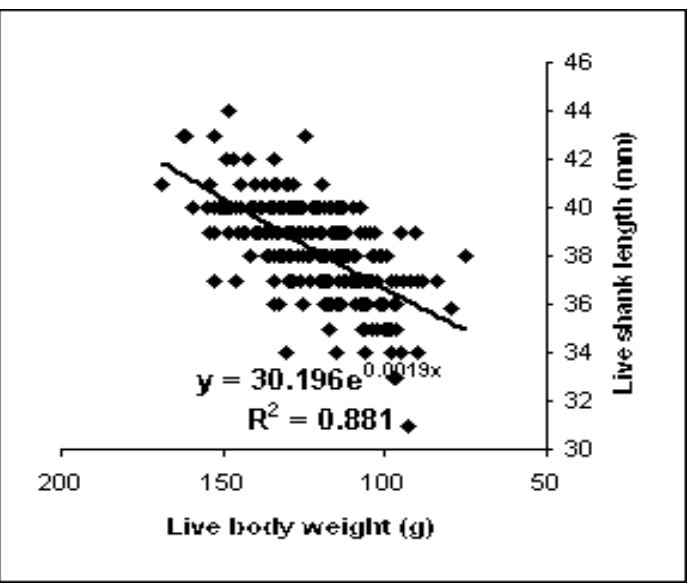

Fayoum J. Agric. Res. \& Dev., Vol.19, No.1, January, 2005 
As shown in Table 6 and Fig.3., the exponential formula $\left(\hat{\mathbf{Y}}=\mathbf{a} \mathbf{e}^{\mathbf{b x}}\right)$ was the best model of fit for the relationship between live body weight and shank length at 24 days of age indicating $\mathrm{R}^{2}$ of 85.8 and $88.1 \%$ for males and females, respectively.

\section{Sex determination through breast feather coloration at different ages}

The juvenile plumage is completely grown at about 28 days after hatching. In males, this plumage of wild-type Japanese quail was brown in color, the breast was reddish brown. Females were similar to males in color, except that the breasts were creamy with dark brown dots. Determining the sex of birds can be done by observing feather patterns and coloration as reported by several investigators (Taka-Tsukasa, 1935, Wetherebee, 1961, Cheng and Kimura, 1993 and Walker, 1996).

Differences between observed and expected count of males and females determined at different ages were subjected to chi-square test as shown in Table 3. Sex determination at 10 and 17 day were significantly different than this obtained at 45 days of age $(\mathrm{P}<0.01)$. However, sexing Japanese quail was successful at 24 days of age and maintained thereafter $(\mathrm{P} \geq 0.05)$.

Paired differences between determined sex at specific age vs. actual sex diagnosed at 45 days of age were tested by Student's t-test are presented in Table 4. Paired differences for 10 and 17 days against actual sex diagnosed at 45 days of age indicated highly significant differences, whereas paired samples at 24 days and thereafter were insignificantly affected as compared with that obtained at 45 days of age.

In conclusion, there were possibilities to determine sex of Japanese quail with a good accuracy through shank length measurements at different ages or breast' feather dimorphism in Japanese quail at 24 days of age and maintained thereafter. Successful management, marketing and breeding programs for Japanese quail requires early identification of sex that it allows farm managers or breeders to separate females in order to use appropriate lighting and nutrition programs for fine maturation and good egg production performance.

Table 3. Accuracy of predicting sex of Japanese quail through breast feather coloration from 10 to 45 days of age sing chi-square test.

\begin{tabular}{|l|c|c|c|c|c|c|}
\hline & 10 & 17 & 24 & 31 & 38 & 45 \\
\hline & Count & Count & Count & Count & Count & Count \\
\hline Questionable & 5 & - & - & - & - & - \\
\hline 0 & 235 & 272 & 415 & 407 & 412 & 414 \\
\hline$q$ & 587 & 555 & 412 & 420 & 415 & 413 \\
\hline Calculated $-\chi^{2}$ & 149.86 & 49.11 & 2.26 & 0.107 & 0.011 & 0.001 \\
\hline Asymptotic. Sig. & $* *$ & $* *$ & NS & NS & NS & NS \\
\hline
\end{tabular}

$:$ female, 0 : male, $\chi^{2}$ : chi-square, Tabulated $-\chi 2=3.84$ and Sig.: significance and $* *: \mathrm{P}<0.01$.

Fayoum J. Agric. Res. \& Dev., Vol.19, No.1, January, 2005 
RESULTS OF TWO MORPHOLOGICAL PRACTICAL MET.

Table 4. Accuracy of predicting sex of Japanese quail through breast feather coloration from 10 to 45 days of age using Student's t-test.

\begin{tabular}{|l|c|c|c|c|c|}
\hline \multicolumn{7}{|c|}{ Paired samples- test } \\
\hline Pair & $10-45$ & $17-45$ & $24-45$ & $31-45$ & $38-45$ \\
\hline Paired difference & 0.242 & 0.168 & $-1.92 \mathrm{E}-03$ & $5.78 \mathrm{E}-03$ & 0.000 \\
\hline Significance & $* * *$ & $* * *$ & NS & NS & NS \\
\hline
\end{tabular}

$* * *$ : $\mathrm{P}<0.001$ and NS: means that sexing insignificantly differed than sexing at 45days of age.

Table 5. Comparison for different curve estimation parameters used for the relationship between live body weight and shank length at different ages.

\begin{tabular}{|l|l|c|l|c|}
\hline \multirow{2}{*}{ Curve type } & \multicolumn{2}{|c|}{ Males } & \multicolumn{2}{c|}{ Females } \\
\cline { 2 - 5 } & \multicolumn{1}{|c|}{ Equation } & $\mathrm{R}^{2}$ & \multicolumn{1}{c|}{ Equation } & $\mathrm{R}^{2}$ \\
\hline Linear & $\hat{\mathrm{Y}}=25.842+0.095 \mathrm{X}$ & 0.861 & $\hat{\mathrm{Y}}=26.674+0.081 \mathrm{X}$ & 0.886 \\
\hline Logarithmic & $\hat{\mathrm{Y}}=-7.209+9.464 \mathrm{Ln}(\mathrm{X})$ & 0.881 & $\hat{\mathrm{Y}}=-6.5525+9.199 \mathrm{Ln}(\mathrm{X})$ & 0.915 \\
\hline Polynomial & $\hat{\mathrm{Y}}=22.761+0.163 \mathrm{X}-0.0003 \mathrm{X}^{2}$ & 0.868 & $\hat{\mathrm{Y}}=22.761+0.1634 \mathrm{X}-0.0003 \mathrm{X}^{2}$ & 0.906 \\
\hline Power & $\hat{\mathrm{Y}}=10.470 \mathrm{X}^{0.2685}$ & 0.896 & $\hat{\mathrm{Y}}=10.858 \mathrm{X}^{0.2571}$ & 0.933 \\
\hline Exponential & $\hat{\mathrm{Y}}=26.817 \mathrm{e}^{0.0027 \mathrm{X}}$ & 0.858 & $\hat{\mathrm{Y}}=27.588 \mathrm{e}^{0.0022 \mathrm{X}}$ & 0.881 \\
\hline
\end{tabular}

Table 6. Comparison for different curve estimation parameters used for the relationship between live body weight and shank length at 24 days of age.

\begin{tabular}{|l|l|c|l|c|}
\hline \multirow{2}{*}{ Curve type } & \multicolumn{2}{|c|}{ Males } & \multicolumn{2}{c|}{ Fquation } \\
\cline { 2 - 5 } & \multicolumn{1}{|c|}{$\mathrm{R}^{2}$} & \multicolumn{1}{c|}{ Equation } & $\mathrm{R}^{2}$ \\
\hline Linear & $\hat{\mathrm{Y}}=30.277+0.066 \mathrm{X}$ & 0.316 & $\hat{\mathrm{Y}}=29.304+0.074 \mathrm{X}$ & 0.411 \\
\hline Logarithmic & $\hat{\mathrm{Y}}=0.746+7.833 \mathrm{Ln}(\mathrm{X})$ & 0.323 & $\hat{\mathrm{Y}}=-3.981-8.817 \mathrm{Ln}(\mathrm{X})$ & 0.409 \\
\hline Polynomial & $\hat{\mathrm{Y}}=24.455+0.163 \mathrm{X}-0.004 \mathrm{X}^{2}$ & 0.328 & $\hat{\mathrm{Y}}=27.414+0.105 \mathrm{X}-0.0001 \mathrm{X}^{2}$ & 0.412 \\
\hline Power & $\hat{\mathrm{Y}}=14.038 \mathrm{X}^{0.2091}$ & 0.319 & $\hat{\mathrm{Y}}=12.567 \mathrm{X}^{0.2321}$ & 0.406 \\
\hline Exponential & $\hat{\mathrm{Y}}=30.917 \mathrm{e}^{0.0017 \mathrm{X}}$ & 0.858 & $\hat{\mathrm{Y}}=30.196 \mathrm{e}^{0.0019 \mathrm{X}}$ & 0.881 \\
\hline
\end{tabular}

\section{REFERENCES}

Cheng, K.M. and Kimura, M. (1993). Mutations and major variants in Japanese quail. pp: 333-362. In: Poultry Breeding and Genetics.edited by R.D. Crawford. Elsevier Science Publishers B.V., Amesterdam, The Netherlands.

Duncan, D.B. (1955). Multiple range and multiple F-tests. Biometrics 11: 1-42.

El Full, E.A. (2000). Effects of slaughter age and sex on carcass composition of Japanese quail. Egypt. J. Poult. Sci. 20: 649-661.

El Full, E.A. (2001). Genetic analysis of hatched egg weight, body weight at different ages and productive performance with their relationships in Japanese quail. Egyptian J. Poult. Sci.21:291-304.

El Full, E.A. and Ragab, M.S. (2004).Stepwise regression analysis for body weight at marketing age in different types of fowls. Fayoum J. Agric. Res. \& Dev. 18: 89-100.

El Full, E.A., Ali, A.A., Abdel Fattah, M.H. and M.A. Khalifa (2001). Inheritance of some growth characteristics of Japanese quail. Egypt. J. Poult. Sci. 21:719-739.

Fayoum J. Agric. Res. \& Dev., Vol.19, No.1, January, 2005 
Jaap, R.G. (1938). Body conformation of the live market turkey. Poult. Sci. $17: 120-125$.

Kawhara, T. (1971). An analysis of sexual dimorphism in body size in the Japanese quail. Genetics 21:111-112.

Kondra, P.A. and Shoffner, R.N. (1955). Heritability of some body measurements and reproductive characters in turkeys. Poult. Sci. 34: $1262-1267$.

Lerner, I.M. (1937). Shank length as a criterion of inherent size. Poult. Sci. 15: 213-215.

Lerner, I.M. (1939). Predictability of body weight from live shank measurements . Poult. Sci. 18: 378-380.

N R C (1994). Nutrient Requirements of Poultry. National Research Councel, $9^{\text {th }}$ revised ed. Nat. Acad. Press, Washington, D. C.

Pepin, D. (1985). Morphological characteristics and sex classification of Redlegged partridge at hatching. J. Wildl. Manage. 49:228-237.

Siopes, T.D. and Wilson, W.O. (1973). Determination of the sex of chukar partridge . J. Wildl. Manage. 37:239- 240.

SPSS (1997). Statistical Package for Social Sciences. Version 8. SPSS Inc.

Taka-Tsukasa, N. (1935). The Birds of Nippon. Vol.1. Witherby, London.

URL (2003). Poultry sexing of day-old chicks. http://msucares.com/poultry/ management/poultry_sexing.html, 2003 Last Modified: Wednesday, 05Mar-03 12: 09:48)

Walker, W.S. (1996). The propagation and commercial use of Bobwhite quail . Quail ANR-516, Reprinted December 1996. Adapted from "Raising Bobwhite Quail For Commercial Use,"Clemson University Cooperative Extension Service, Circular 514, by W. S. Walker .

Weaver, H.P. and Haskell, W.L. (1968). Age and sex determination of the chukar partridge. Wildl. Manage. 32:46-240.

Wetherebee, D.K. (1961). Investigations in the life history of the common coturnix. Am. Midl. Nat. 65: 168-186.

Woodard, A.E., Hermes, J.C. and Fuqua, L. (1986). Shank length for determining sex in Chukars. Poult. Sci. 65: 627-630.

$$
\begin{aligned}
& \text { نتائج طريقتين مظهريتين تطبيقيتين لتحديد الجنس فى السمان اليابانى }
\end{aligned}
$$

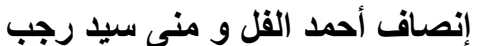

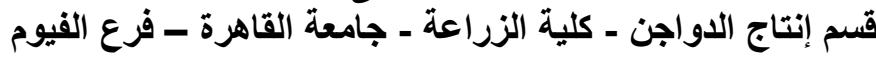

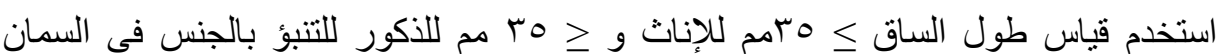

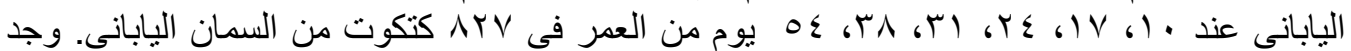

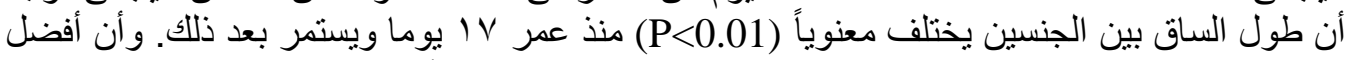

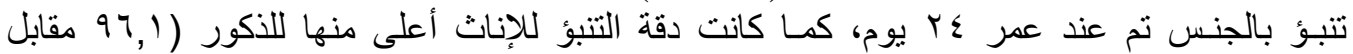

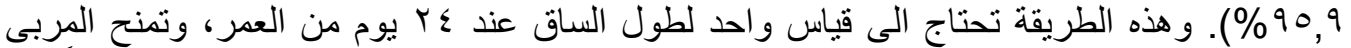

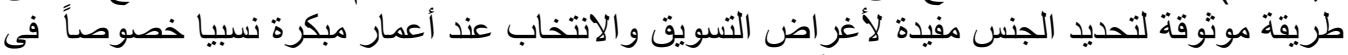

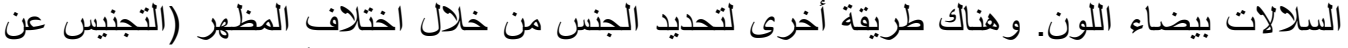
طريق الريش) بدرجة دقة 90\% عند عمر ؟ ب يوم. لذللك فكل من طول الساق أو اختلاف الريش يمكن أن يعد طريقة فعالة لفصل الجنسين فى السمان اليابانى.

Fayoum J. Agric. Res. \& Dev., Vol.19, No.1, January, 2005 